\title{
Slaughterhouses sustainability analysis in special capital region of Jakarta Province, Indonesia
}

\author{
H. A. Sidabalok ${ }^{1}$, Macfud Macfud ${ }^{2}$, N. Ramli ${ }^{3}$ and N. K. Pandjaitan ${ }^{4}$
}

1. Study Program of School of Environment Science, IPB Graduate School, Bogor Agricultural University, Bogor, Indonesia; 2. Department of Agroindustrial Technology Bogor Agricultural University, Bogor, Indonesia; 3. Department of Nutrition and Feed Science Bogor Agricultural University, Bogor, Indonesia; 4. Department of Communication and Community Development Bogor Agricultural University, Bogor, Indonesia.

Corresponding author: H. A. Sidabalok, e-mail: hasudungansidabalok@yahoo.co.id

Co-authors: MM: machfud21@gmail.com, NR: nahrowi@ipb.ac.id, NKP: nurmala_katrina@yahoo.co.id Received: 10-01-2019, Accepted: 16-04-2019, Published online: 04-06-2019

doi: 10.14202/vetworld.2019.748-757 How to cite this article: Sidabalok HA, Macfud M, Ramli N, Pandjaitan NK (2019) Slaughterhouses sustainability analysis in special capital region of Jakarta Province, Indonesia, Veterinary World, 12(6): 748-757.

\begin{abstract}
Aim: The objective of this research was understanding slaughterhouses sustainability and the prospection status in special region of Jakarta Province Indonesia.

Materials and Methods: The concept of sustainable slaughterhouse was formed based on social, economy, ecology, technology, and institutional dimension. Research objects were three types of slaughterhouses in Special Capital Region of Jakarta Indonesia; pig slaughterhouse, chicken slaughterhouse, and ruminant slaughterhouse. Tools used were questionnaires to assess the perception of people living around slaughterhouses, assessment of the knowledge, attitude, and practice from slaughterhouse management, along with assessment and focus group discussion for sustainability test. Methods used were descriptive analysis and sustainability test by multidimensional scaling method. Data collected consisted of primary and secondary data. Primary data were obtained by field survey, interview, questionnaire, measurement of the waste threshold, and microbe contamination, whereas secondary data were obtained from slaughterhouse agency. Data were analyzed with IBM statistical package for the social sciences (SPSS ${ }^{\circledR}$ ) version 18 to calculate characteristic, variables correlation, sustainability test with Rapfish ${ }^{\circledR}$ modified into Rap slaughterhouse, and prospective analysis with PPA.
\end{abstract}

Results: The level of sustainability for pig slaughterhouse was moderately sustainable with 0.5173 index value, ruminant slaughterhouse was moderately sustainable with 0.5171 index value, and chicken slaughterhouse was moderately unsustainable with 0.4530 index value.

Conclusion: Scenario on policies that should be applied in ruminant slaughterhouse was increasing the use of waste as biogas; for chicken slaughterhouse was increasing promotion and for pig slaughterhouse was increasing product quality control. The implication of this research was to provide input based on a scientific study for the local government of Jakarta in managing the slaughterhouses.

Keywords: attitude, knowledge, practice, slaughterhouse, sustainability.

\section{Introduction}

Based on The Center of Statistical Data (Badan Pusat Statistik) [1] for Jakarta Province, the population of Jakarta in 2017 was 10,377,924 peoples. In 2017, the demand for beef, chicken meat, and pork in Jakarta were 60.376 tonnes, 365.000 tonnes, and 1.000 tonnes, respectively. Only $20 \%$ of the demand could be fulfilled by slaughterhouses in Jakarta, which were ruminant slaughterhouse in Cakung, pig slaughterhouse in Kapuk, and chicken slaughterhouse in Rawa Kepiting. The rest of the demand was fulfilled by slaughterhouses outside of Jakarta.

Based on Law Number 18 of 2009 concerning Animal Husbandry and Animal Health and its

Copyright: Sidabalok, et al. Open Access. This article is distributed under the terms of the Creative Commons Attribution 4.0 International License (http://creativecommons.org/licenses/ by/4.0/), which permits unrestricted use, distribution, and reproduction in any medium, provided you give appropriate credit to the original author(s) and the source, provide a link to the Creative Commons license, and indicate if changes were made. The Creative Commons Public Domain Dedication waiver (http:// creativecommons.org/publicdomain/zero/1.0/) applies to the data made available in this article, unless otherwise stated. amendments to Law No. 41 of 2014 Article 6, which requires slaughter of animals whose meat is circulated to be carried out in slaughterhouses and must follow slaughter methods that meet veterinary public health rules and animal welfare. The implementation of the Law is elaborated through Government Regulation of the Republic of Indonesia Number 95 of 2012 concerning Public Health Veterinary and Animal Welfare, which regulates the operation of slaughterhouses. [2]. Animal slaughter industry in principle is a way to improve living standard and economy although the waste may cause an inevitable negative impact on environmental balance. Good hygiene and sanitation are implemented to suppress bacterial growth in an indicator of the existence of fecal and pathogenic bacterial contamination, which needed improvement [3]. Environmental management is done to prevent a negative impact on public health be it to people who consume the product originating from animal slaughterhouses or to people who live near animal slaughterhouses [4].

Researches on sustainability slaughterhouse needed to be done so that slaughterhouses management 
can implement sanitary hygiene practices and good waste management, orienting on profit by considering social and public health aspect, technology implementation and dynamic institutional coordinating [5].

The objective of this research was to analyze the sustainability of slaughterhouses especially in three slaughterhouses: Ruminant slaughterhouse, poultry slaughterhouse, and pig slaughterhouse based on social, economic, ecological, technological, and institutional dimension, and then determining policy scenario for sustainable slaughterhouse implementation in Jakarta Province Indonesia.

\section{Materials and Methods}

\section{Ethical approval}

The approval to conduct this study was obtained via the following permissions: permission from DKI Jakarta Provincial Health Office with the approval number, 672/SDK/VI/2017; a letter of recommendation from the chairman of the study program of natural resource management and environment of Bogor Agricultural University, with the SK number 316/ IT3.10.2/KM/2017.

\section{Informed consent of participants}

Informed consent was obtained from all the participants/respondents.

\section{Research time and location}

The research was done between April 2018 and August 2018 in the following locations: (1) Cakung for ruminant slaughterhouse; (2) Rawa Kepiting for poultry slaughterhouse; and (3) Kapuk for pig slaughterhouse. Slaughterhouse determination was done by purposive sampling based on certain criteria.

\section{Research concept framework}

Slaughterhouse sustainability analysis in Jakarta Province was compiled out of several dimensions: Social (S), economical (Ec), environmental (En), institutional (I), and technological (T) dimension. These attributes consisted of characteristics and perceptions from people around slaughterhouse, the management of slaughterhouse, stakeholders of slaughterhouse, academician/professionals, and observation results in the form of primary and secondary data. The assessment result from these attributes would be the sustainability dimension assessment value measured by multidimensional scaling (MDS) method. Afterward, the prospective analysis was done to observe the main triggering attribute in managing sustainable slaughterhouse using participatory prospective analysis (PPA) method. This status was used as the basis of policy scenario so that sustainable management of animal slaughterhouse could be achieved.

\section{Respondent and data source}

There were 108 local resident respondents from all slaughterhouses, which consisted of 40 respondents from ruminant slaughterhouse, 43 respondents from chicken slaughterhouse, and 25 respondents from pig slaughterhouse. The respondent's criteria were influential residents or head of family within $1 \mathrm{~km}$ radius of the slaughterhouse [6]. The number of slaughterhouse worker respondents was 108 respondents with 45 respondents from ruminant slaughterhouse, 33 respondents from chicken slaughterhouse, and 30 respondents from pig slaughterhouse with sample size depending on the proportion of the number of workers in every slaughterhouse, which may comprise butchers, waste worker, health worker, and management worker. Sample gathering technique to acquire information and knowledge from stakeholders and professionals used expert survey method through in-depth interview and focus group discussion under purposive sampling to determine dimension, data sources and references for sustainable slaughterhouse management (Table-1). Respondents consisted of PD. Dharma Jaya Chief Director, head of Puskesmas (local government clinic), the head of the animal husbandry, the head of slaughterhouse management section, and professional/academician. Questionnaire respondents for PPA were PD Dharma Jaya Director, the head of food security, marine, and agriculture agency of Jakarta Province, the head of Jakarta Province economy bureau, the head of animal husbandry division, the head of slaughterhouse, and competent professional/academician.

\section{Statistical analysis}

Data analysis consisted of several stages, which were situational analysis from primary and secondary data followed by multidimensional analysis (MDS) with Rapfish software, which was modified into Rap slaughterhouse. Rapfish is a statistical technique for rapid appraisal of relative status of entities (=fisheries), judged quantitatively against pre-defined sets of attributes grouped into "evaluation fields" or disciplines. The Rapfish technique is flexible such that other modalities of status may be used, such as conformity with a set of specified objectives or compliance with a code of conduct. Multidimensional scaling analysis consisted of ecology, economy, social, technology, and institutional of every slaughterhouse. Attributes from dimension were scored based on the real data condition in the field be it from interview and observation (primary data) or using secondary data. Scoring was based on references from literature and judgment in accordance with scientific assumptions and principles. Scores obtained were then inputted into excel with previously prepared template and then processed until Rap slaughterhouse value was obtained, called sustainability index. The sustainability index value was separated into four levels, 0-25 range was within bad/unsustainable status, 26-50 range was fairly unsustainable, 51-75 range was moderately sustainable, and 76-100 was within sustainable [19].

The most influential attributes in every dimension were arranged in a questionnaire to determine the effect and dependence of every attribute through a prospective test to obtain essential factor for policy 
Table-1: Dimension, data source and references for sustainable slaughterhouse management.

\begin{tabular}{|c|c|c|c|}
\hline Code & Environmental dimension attributes & Data source & References \\
\hline En1 & Recording of number of slaughters every day & Observation & {$[7-10]$} \\
\hline En2 & $\begin{array}{l}\text { Temporary shelter and slaughter area cleaning } \\
\text { frequency }\end{array}$ & Observation & \\
\hline En3 & Waste pipe/drainage leakage & Observation & \\
\hline En4 & Waste and rain water separation & Observation & \\
\hline En5 & Waste control with debt measuring device & Observation & \\
\hline En6 & Separation of liquid and solid waste & Observation & \\
\hline En7 & Incinerator & Observation & \\
\hline En8 & Waste usage as organic fertilizer or biogas & Observation & \\
\hline En9 & Waste threshold control & Laboratory test and data from management & \\
\hline En10 & $\begin{array}{l}\text { General knowledge of slaughterhouse waste } \\
\text { management }\end{array}$ & Questionnaire & \\
\hline En11 & Soil pollution & Questionnaire & \\
\hline En12 & Flood location & Questionnaire & \\
\hline Code & Economy dimension attributes & Data source & References \\
\hline Ec1 & Region retribution target & Secondary data & {$[1,11,12]$} \\
\hline Ec2 & Market share & Secondary data & \\
\hline Ec3 & Slaughterhouse product marketing coverage & Secondary data & \\
\hline Ec4 & Demand level & Secondary data & \\
\hline Ec5 & Promotion & Secondary data & \\
\hline Ec6 & Product health control & Questionnaire & \\
\hline Ec7 & Livestock supply sustainability & Secondary data & \\
\hline Ec8 & Livestock life quality control & Questionnaire & \\
\hline Ec9 & Businesses other than meat industry & Secondary data & \\
\hline Ec10 & People's economical perception & Questionnaire & \\
\hline Ec11 & Slaughterhouse worker/management learning level & Questionnaire & \\
\hline Code & Social dimension attributes & Data source & References \\
\hline S1 & Health status of slaughterhouse worker & Questionnaire & {$[6,7,13,14]$} \\
\hline S2 & Disease prevalence in people & Secondary data & \\
\hline S3 & $\begin{array}{l}\text { Slaughterhouse microbiological sample } \\
\text { examination }\end{array}$ & Lab examination and secondary data & \\
\hline S4 & Worker level of education & Questionnaire & \\
\hline S5 & $\begin{array}{l}\text { Slaughterhouse acceptance perception of local } \\
\text { people }\end{array}$ & Questionnaire & \\
\hline S6 & Waste-related disease in local people & Questionnaire & \\
\hline S7 & Disease frequency & Questionnaire & \\
\hline S8 & $\begin{array}{l}\text { Slaughterhouse management level of knowledge } \\
\text { on hygiene, sanitation, and waste management }\end{array}$ & Questionnaire & \\
\hline S9 & $\begin{array}{l}\text { Slaughterhouse management concerning hygiene, } \\
\text { sanitation, and waste management }\end{array}$ & Questionnaire & \\
\hline S10 & $\begin{array}{l}\text { Slaughterhouse management practice on hygiene, } \\
\text { sanitation, and waste management }\end{array}$ & Questionnaire & \\
\hline S11 & $\begin{array}{l}\text { Slaughterhouse worker training frequency on } \\
\text { slaughterhouse worker as profession }\end{array}$ & Questionnaire & \\
\hline Code & Technology dimension attributes & Data source & References \\
\hline T1 & Biogas technology implementation & Observation & {$[7,15,16]$} \\
\hline T2 & Organic fertilizer technology implementation & Observation & \\
\hline T3 & GHP implementation & Questionnaire & \\
\hline T4 & Cold chain implementation in product distribution & Secondary data & \\
\hline T5 & Slaughter system characteristic & Observation & \\
\hline T6 & Slaughterhouse product diversification & Secondary data & \\
\hline Code & Institutional dimension attributes & Data source & References \\
\hline I1 & $\begin{array}{l}\text { Slaughterhouse location suitability with general } \\
\text { layout plan of Jakarta }\end{array}$ & Secondary data & {$[17,18]$} \\
\hline I2 & Slaughterhouse operational alliance & Secondary data & \\
\hline I3 & Coordination pattern with livestock supplier region & Interview & \\
\hline I4 & Cooperation with businesses from other regions & Interview & \\
\hline I5 & Transactional coordination pattern & Interview & \\
\hline I6 & $\begin{array}{l}\text { Productive female livestock slaughter ban } \\
\text { policy (ruminants) }\end{array}$ & Questionnaire & \\
\hline I7 & Live livestock import policy (ruminant) & Interview & \\
\hline
\end{tabular}

GHP $=$ Good hygiene practices 
scenario in developing the current studied system. The method used was PPA through pairwise comparison approach to see the effect and dependence of every attribute between each other to obtain measured global value from every dimension considered as main attributes [20].

\section{Results}

Multidimensional scaling and sustainability validation analysis in ruminant slaughterhouse

Analysis result of MDS method in ruminant slaughterhouse generated the sustainability value of every dimension. Economy, institutional, and technology dimension sustainability status were considered as moderately sustainable with sustainability value $>50$ with economy dimension being 56.76 , institutional dimension being 53.52, and technology dimension being 56.33. Dimensions on fairly sustainable category were ecology dimension with 46.51 and social dimension with 45.37; thus, efforts are needed to improve sustainability in ecology and social dimension. Visualization of kite diagram to illustrate the sustainability status between dimensions is observed in Figure-1.

The validity of MDS analysis was confirmed by Monte Carlo analysis. The gap between MDS analysis result with Monte Carlo comparison value was $<5 \%$ or really small, which means that the level of faults that may influence MDS process was $>5 \%$, that the influence of faults to attributes scoring was very small (Table-2).

\section{MDS and sustainability validation analysis in chicken} slaughterhouse

Analysis result using MDS method in chicken slaughterhouse showed the sustainability value of every dimension. Sustainability status of economy dimension was categorized as moderately sustainable with 53.64; however, the rest of the value were included as fairly sustainable with social dimension being 32.50 , ecology dimension being 46.51 , institutional dimension being 30.61, and technology dimension being 39.95 (Figure-2).

Validity of MDS analysis was confirmed by Monte Carlo analysis. The gap between MDS analysis result with Monte Carlo comparison value was $<5 \%$ or really small, which means that the level of faults that may influence MDS process was $>5 \%$ (Table-3). From the analysis, it can be summarized that the influence of faults to attributes scoring was very small.

MDS and sustainability validation analysis in pig slaughterhouse

Analysis result using MDS method in pig slaughterhouse showed the sustainability value of every dimension. The sustainability status of economy dimension was categorized as moderately sustainable with 65.33, while other dimensions were categorized as not so sustainable with social dimension being 45.17, ecology dimension being 46.51, institutional dimension being 46.52 , and technology dimension being 42.23 (Figure-3).

The validity of MDS analysis was confirmed by Monte Carlo analysis. The gap between MDS analysis result with Monte Carlo comparison value was $<5 \%$ or really small, which means that the level of faults that may influence MDS process is $>5 \%$. From the analysis, it can be summarized that the influence of faults to attributes scoring was very small (Table-4).

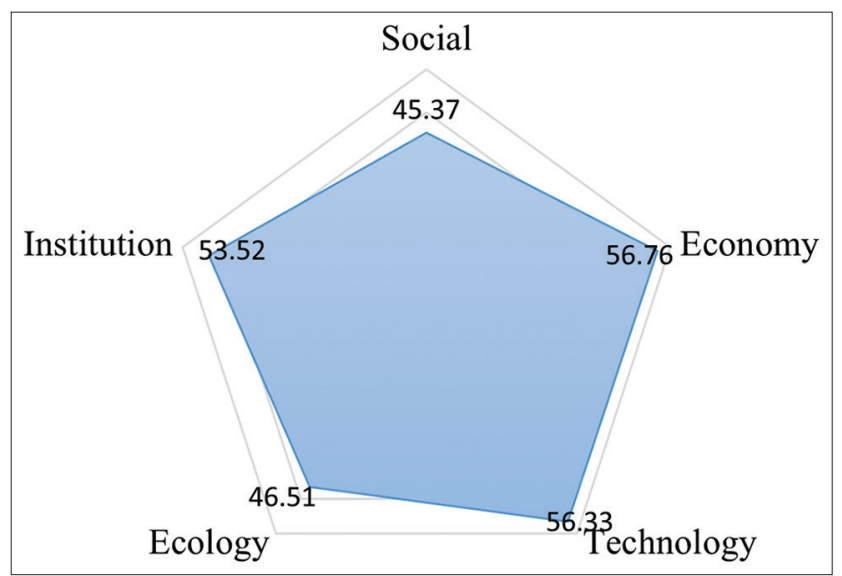

Figure-1: Kite diagram of ruminant slaughterhouse.

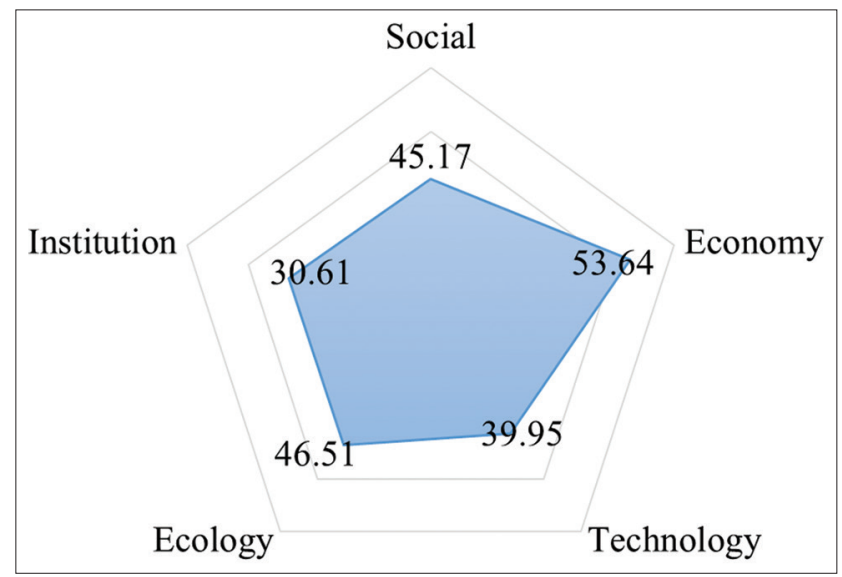

Figure-2: Kite diagram of chicken slaughterhouse.

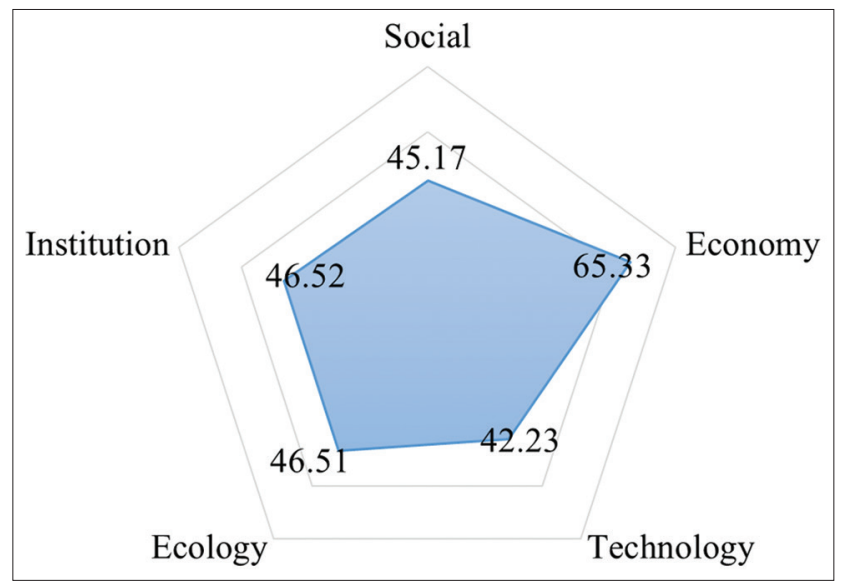

Figure-3: Kite diagram of pig slaughterhouse. 


\section{Animal slaughterhouse sustainability analysis}

In general, economy dimension was grouped as moderately sustainable $(>50)$. This indicated that every slaughterhouse must be benefitting economically, while dimension with the least sustainability was social dimension (between 25 and 50) since many people did not agree with the existence of slaughterhouse and many also suffered diseases caused by slaughterhouse waste. In general, ruminant and pig slaughterhouse were grouped as sustainable with sustainability index ranging between 51 and 75 and chicken slaughterhouse was grouped as less sustainable with index ranging 26-50 (Figure-4).

Sustainability in every dimension was affected by a leverage factor. Leverage factor is the most sensitive factor against intervention if effort for sustainability development intervened the given factor. There were 23 most influential factors in ruminant slaughterhouse, 24 attributes in chicken slaughterhouse, and 19 attributes in pig slaughterhouse (Table-5).

Table-2: Calculation of sustainability index and validation in ruminant slaughterhouse.

\begin{tabular}{lcccrr}
\hline Dimension & Dimension status & Monte Carlo & Delta & RSQ & Stress \\
\hline Social & 45.37 & 46.06 & 0.69 & 0.9486 & 0.1320 \\
Economy & 56.76 & 56.05 & 0.71 & 0.9533 & 0.1348 \\
Ecology & 46.51 & 46.23 & 0.28 & 0.9534 & 0.1368 \\
Institution & 53.52 & 53.66 & 0.14 & 0.9393 & 0.1482 \\
Technology & 56.33 & 56.20 & 0.13 & 0.9433 & 0.1490 \\
\hline
\end{tabular}

$\mathrm{RSQ}=$ Responses to stress questionnaire

Table-3: Calculation of sustainability index and validation in chicken slaughterhouse.

\begin{tabular}{lcccrr}
\hline Dimension & Dimension status & Monte Carlo & Delta & RSQ & Stress \\
\hline Social & 32.50 & 34.56 & 2.06 & 0.9471 & 0.1316 \\
Economy & 53.64 & 53.34 & 0.30 & 0.9517 & 0.1303 \\
Ecology & 46.51 & 46.23 & 0.28 & 0.9534 & 0.1368 \\
Institution & 30.61 & 32.32 & 2.71 & 0.9478 & 0.1376 \\
Technology & 39.95 & 41.64 & 1.69 & 0.9334 & 0.1434 \\
\hline
\end{tabular}

$\mathrm{RSQ}=$ Responses to stress questionnaire

Table-4: Complete calculation of sustainability index and validation in pig slaughterhouse.

\begin{tabular}{lcccrr}
\hline Dimension & Dimension status & Monte Carlo & Delta & RSQ & Stress \\
\hline Social & 45.17 & 45.62 & 2.06 & 0.9490 & 0.1317 \\
Economy & 65.33 & 64.03 & 0.30 & 0.9535 & 0.1309 \\
Ecology & 46.51 & 46.23 & 0.28 & 0.9534 & 0.1368 \\
Institution & 46.52 & 46.49 & 2.71 & 0.9383 & 0.1550 \\
Technology & 42.23 & 42.47 & 1.69 & 0.9299 & 0.1473 \\
\hline
\end{tabular}

$\mathrm{RSQ}=$ Responses to stress questionnaire

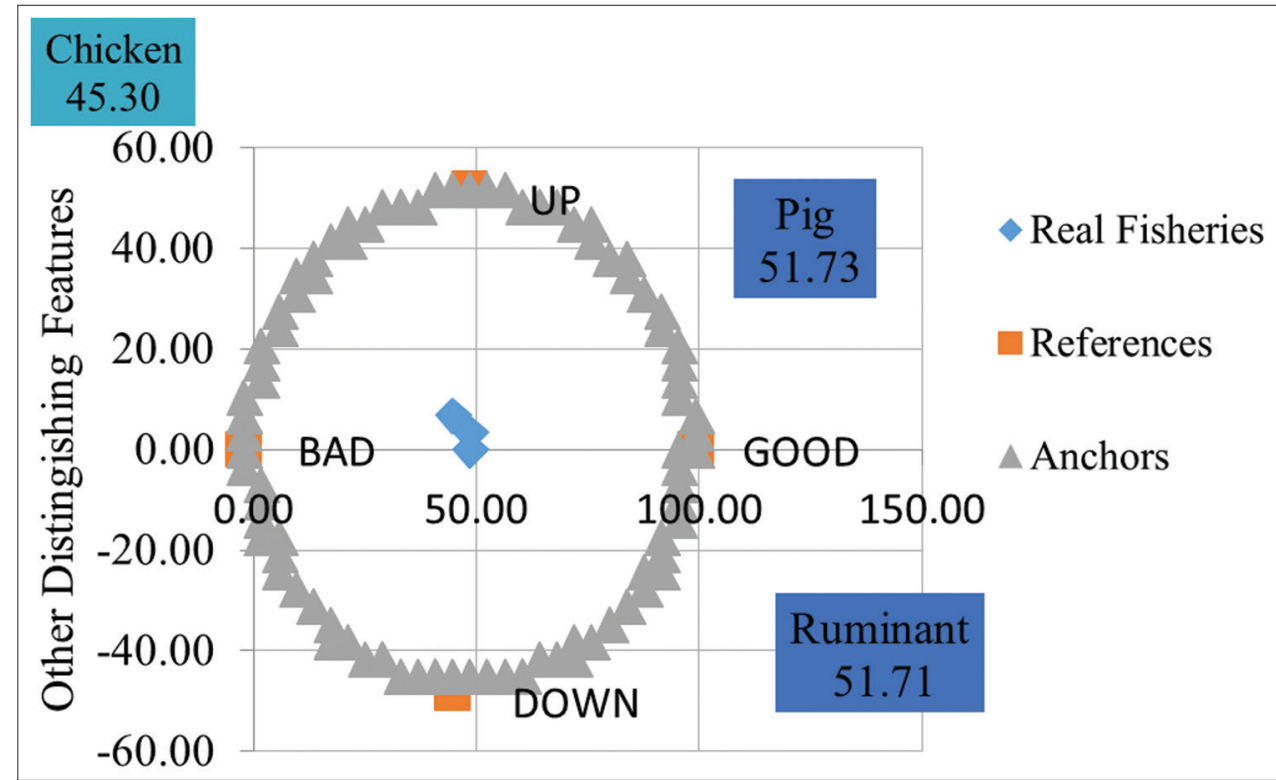

Figure-4: Sustainability status of every slaughterhouse. 


\section{Ruminant slaughterhouse prospective test}

Based on the prospective analysis, En8 and S8 codes were attributed with the highest influence factor and low dependability on other attributes. This means the two attributes have the highest global value out of all leverage factors (Figure-5).

Waste water usage attribute (S8) was a variable with the highest global weight so in developing sustainable ruminant slaughterhouse, waste management must be especially enforced. Waste management was the most neglected part of management in slaughterhouses, especially in a developing country. Moreover, there was a preconception that waste management required big effort and funding that it might affect whole operational cost [21]. More on the weighted global power value of ruminant slaughterhouse is provided in Table- 6 .

\section{Chicken slaughterhouse prospective test}

Prospective analysis test result on chicken slaughterhouse based on variable placements inside quadrants and weighted global powers showed that the main leverage or key variables in sustainable poultry slaughterhouse were attributes with code Ec5, En8, S9, and En5 (Figure-6).

In chicken slaughterhouse, promotion attribute was the main most influential attributes because the existence of chicken slaughterhouse was not well known among local people and other business stakeholders compared to other slaughterhouses. Chicken slaughterhouse has only been in operation for about 10 years (Table-7).

\section{Pig slaughterhouse prospective test}

The prospective analysis test result showed that the main leverage attribute in pig slaughterhouse was

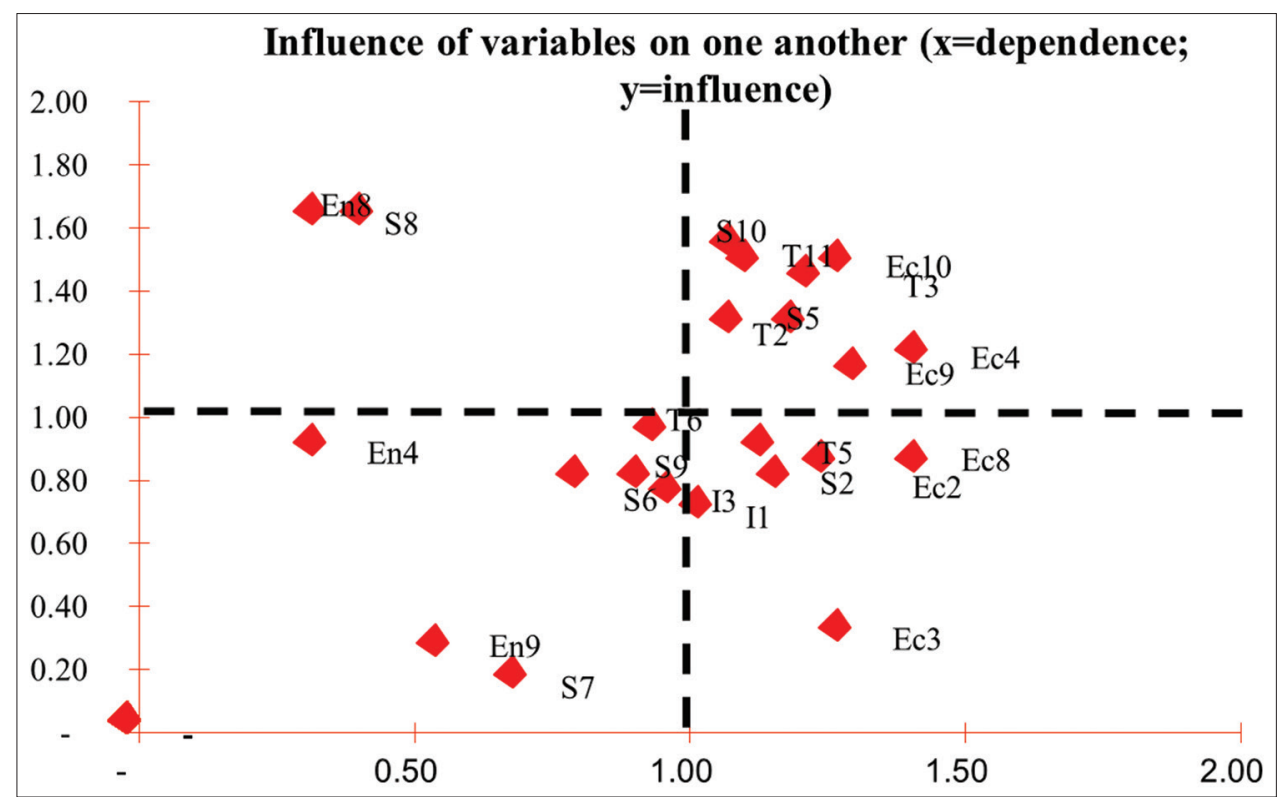

Figure-5: Attribute position of ruminant slaughterhouse.

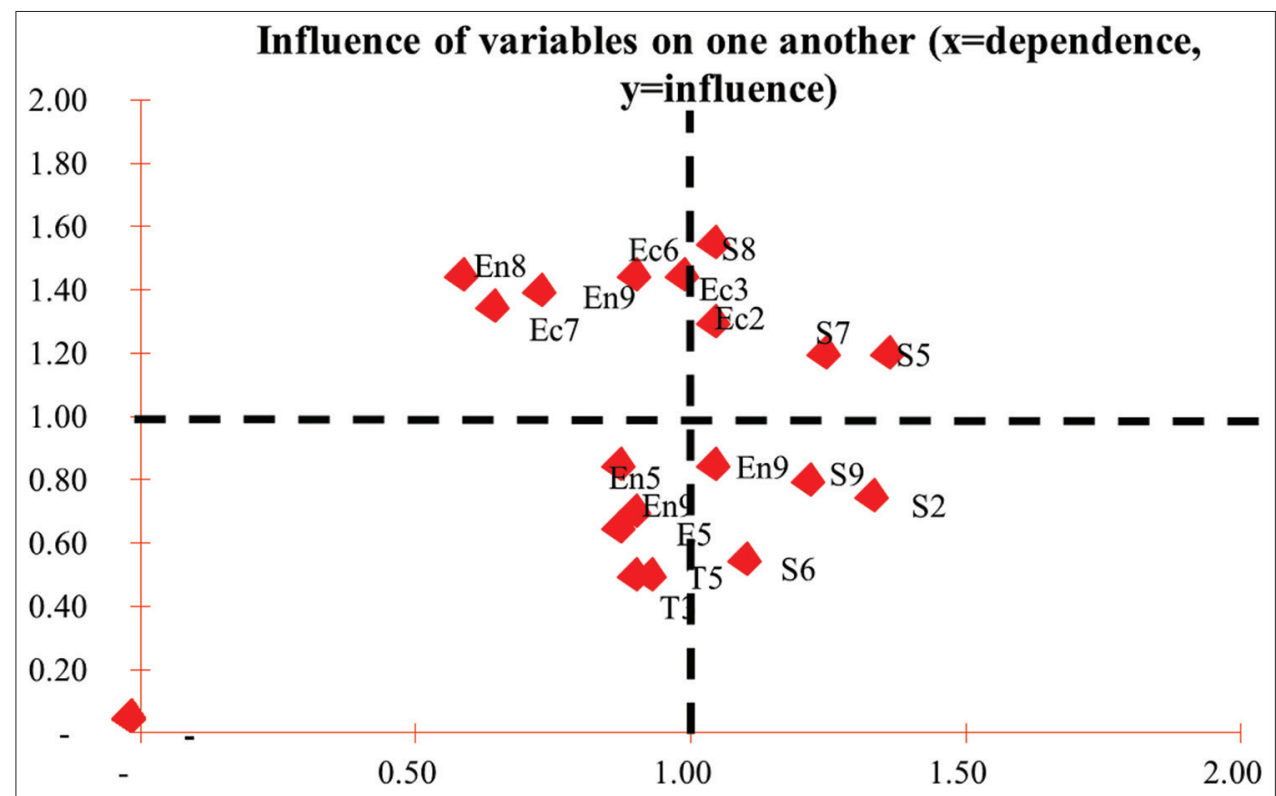

Figure-6: Attributes' position in chicken slaughterhouse. 
slaughterhouse product quality control (En6) and the usage of slaughterhouse waste as organic fertilizer/ biogas. This was because there was a lack of veterinarians as meat health supervisor (Figure-7).

In pig slaughterhouse, slaughterhouse product quality control was the most influential factor due to the lack of supervisory units in the slaughterhouse (Table-8).

\section{Discussion}

Ruminants slaughterhouse

Sustainability analysis result by MDS method in economy, institutional, and technology dimension was

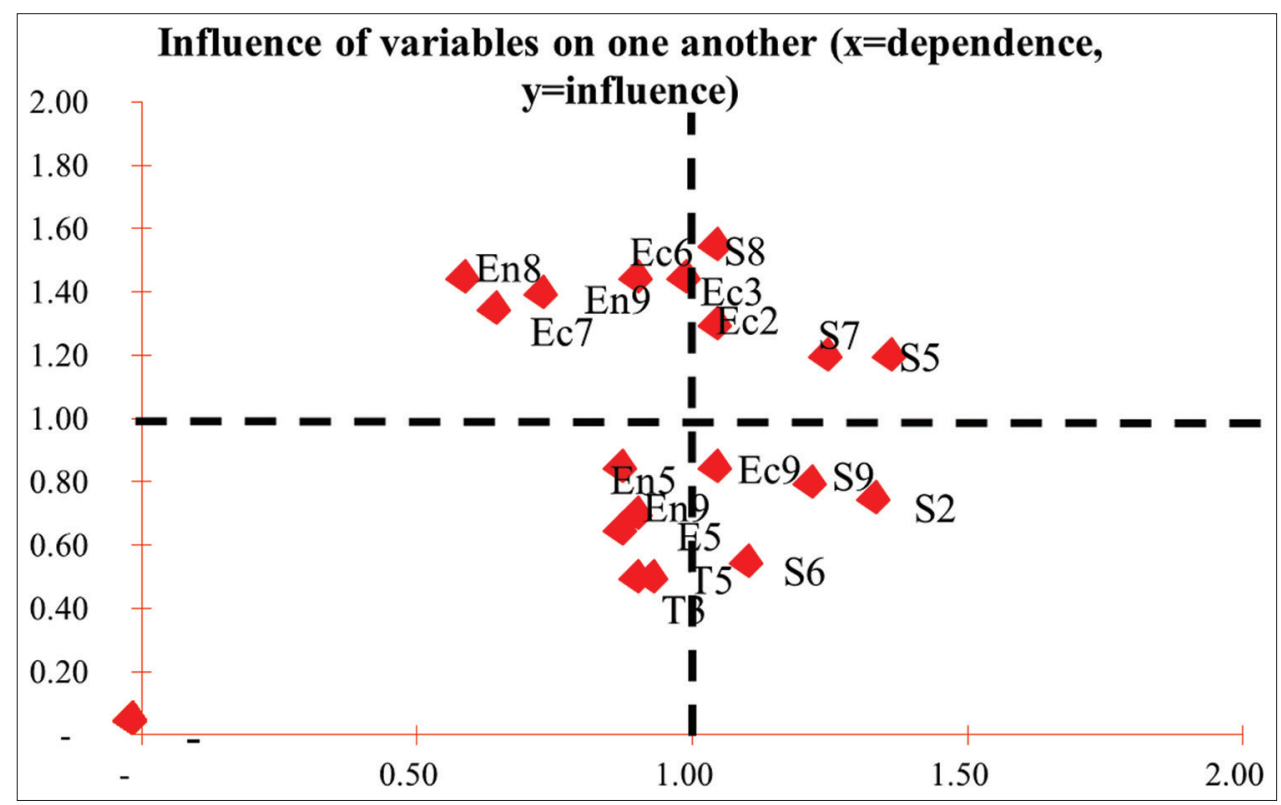

Figure-7: Attributes position in pig slaughterhouse.

Table-5: Most influential attributes in every dimension from every slaughterhouse.

\begin{tabular}{|c|c|c|c|c|c|}
\hline \multirow[t]{2}{*}{ Slaughterhouse } & \multicolumn{5}{|c|}{ Dimension main leverage factor } \\
\hline & Social & Economy & Environment & Institutional & Technology \\
\hline Ruminant & $\mathrm{S} 5, \mathrm{~S} 6, \mathrm{~s} 7, \mathrm{~s} 2, \mathrm{~S} 8, \mathrm{~S} 4, \mathrm{~S} 9$ & Ec9, Ec4, Ec10, Ec2, Ec6 & En5, En 8, En 9 & I3, I 1 & $\mathrm{~T} 5, \mathrm{~T} 6, \mathrm{~T} 3, \mathrm{~T} 1$ \\
\hline Chicken & S8, S5, S2, s9, S4, s7, s6 & Ec5, Ec8, Ec4, Ec3 & En 5, En 8, En 9 & I 4, I 1, I 5 & T5, T3, T2 \\
\hline Pig & $\mathrm{S} 5, \mathrm{~s} 6, \mathrm{~s} 7, \mathrm{~s} 2, \mathrm{~s} 8, \mathrm{~s} 9, \mathrm{~s} 3$ & Ec5, Ec3, Ec6, Ec7, Ec9 & En 5, En 8, En 9 & I 1, I 2 & T3, T5 \\
\hline
\end{tabular}

Table-6: Global weighted power of ruminant slaughterhouse.

\begin{tabular}{llc}
\hline Code & Leverage attributes & Global weighted power \\
\hline En8 & Water waste utilization (organic fertilizer/biogas) & 2.96 \\
S8 & Management level of knowledge on hygiene and sanitation & 2.74 \\
T1 & Waste into energy source technology & 2.00 \\
Ec10 & Economic benefit for local residents & 1.94 \\
T3 & Good hygiene practices implementation & 1.65 \\
S4 & Slaughterhouse worker level of education & 1.59 \\
S5 & Local residents' acceptance & 1.37 \\
T2 & Waste into organic fertilizer technology & 1.17 \\
En4 & Level of demand & 0.54 \\
En9 & Involved stakeholders (other than meat production) & 0.52 \\
\hline
\end{tabular}

Table-7: Weighted global power of chicken slaughterhouse.

\begin{tabular}{llc}
\hline Symbol & Leverage attributes & Global weighted power \\
\hline Ec5 & Promotion & 2.83 \\
En8 & Waste water utilization (organic fertilizer/biogas) & 2.68 \\
S7 & Disease frequency in a year & 2.16 \\
En5 & Waste supervision by related institution & 2.09 \\
S2 & Local resident's health problems & 1.87 \\
S9 & Slaughterhouse management's stance on hygiene and sanitation & 1.54 \\
I2 & Slaughterhouse management/operation alliance & 1.22 \\
I3 & Coordination with livestock supplier region & 0.57 \\
\hline
\end{tabular}


Table-8: Weighted global power of pig slaughterhouse.

\begin{tabular}{llc}
\hline Symbol & Leverage attributes & Weighted global power \\
\hline Ec6 & Slaughterhouse product quality control & 2.03 \\
En8 & Waste water utilization (organic fertilizer/biogas) & 1.95 \\
Ec3 & Production & 1.82 \\
S8 & Management level of knowledge on hygiene and & 1.74 \\
& sanitation & 1.66 \\
En9 & Waste threshold examination & 1.65 \\
En3 & Product marketing region & 1.50 \\
En7 & Livestock supply sustainability & 0.98 \\
S7 & Local people disease frequency & 0.82 \\
\hline
\end{tabular}

included as moderately sustainable with sustainability index $>50$. The sustainability of the three dimensions was influenced by main leverage factor, which a factor most sensitive to changes. Thus, to improve the sustainability of dimensions, treatment must be applied on leverage factor [22]. Main leverage factor in economy dimension was the involvement of other business stakeholders in slaughterhouse management other than slaughter business. The examples of these businesses are tanning, fertilizer business, and other types of business. High demand for beef in Jakarta Province could improve economy dimension only if slaughterhouse productivity is improved, as currently, the slaughterhouse could only fulfill $5.2 \%$ of total demand [1]. The main leverage factor of institutional dimension was coordination pattern with supplier province. All animals slaughtered in the slaughterhouse came from supplier province since Jakarta is unsuitable for cow production. Coordination with livestock producing province must be maintained to ensure the continuity of livestock supply. Other than coordination, the suitability of slaughterhouse location must be in accordance with the general plan layout of DKI Jakarta Province. The main leverage factor of technology dimension was whether or not the slaughterhouse already implemented automatic, semi-automatic, or manual slaughter system. The current slaughterhouse had already implemented a semi-automatic system, which influences the quality and quantity of slaughter. The slaughterhouse also already produced meatballs, which is an example of product diversification into processed products.

Prospective test on every attribute with PPA method using questionnaire/tools different from MDS method obtained global weighted value. The global weight value is the value with the highest influence and lowest dependability level, which means that it is the main attribute that can be improved to enhance the sustainability of ruminant slaughterhouse management [23]. The highest global weight values for the slaughterhouse were utilization of liquid and solid waste into organic fertilizer where the highest potential for using slaughterhouse waste to be used as biogas is stomach waste (entire digestive tract), manure, and waste blood [21], and the level of knowledge of abattoir workers related to hygiene and sanitation has a correlation with knowledge and attitude [24]. In this ruminant slaughterhouse, $60 \%$ of slaughterhouse employee had the level of knowledge which is within good category, for sanitation, and hygiene [25].

\section{Poultry slaughterhouse}

High demand on chicken meat in Jakarta Province could improve economy dimension only if slaughterhouse productivity is improved, as currently, the slaughterhouse could only fulfill $7.89 \%$ of total demand [1]. The sustainability of the three dimensions was influenced by main leverage factor, which a factor most sensitive to changes. Thus, to improve the sustainability of dimensions, treatment must be applied on leverage factor [22]. For poultry slaughterhouse, dimensions included as moderately sustainable was only the economy dimension with index value being $>50$ while other dimensions fell into less sustainable. In economy dimension, the main leverage attribute was the promotion campaign of slaughterhouse and its products and whether or not there was quality control during antemortem and postmortem. If this main attribute can be improved, the sustainability of economy dimension can increase surpassing moderate sustainability into the sustainable stage. Social, ecology, management, and technology dimension in this slaughterhouse were categorized as fairly sustainable with $<50$ sustainability index. To improve the sustainability status for every dimension, an improvement on main leverage factors of every dimension is required. In social dimension, improvement in employee level of knowledge and hygiene and sanitation was required since $72.7 \%$ of respondents have good knowledge and there is a clear correlation between education levels with knowledge, attitude [21]. Improvement in the local perception of slaughterhouse existence was also required since $32.6 \%$ of locals are disturbed by the existence of the slaughterhouse. In ecology dimension, the main leverage factor was the availability of waste monitoring apparatus. If waste monitoring apparatus is available and waste is utilized as organic fertilizer and biogas, the attribute will be guaranteed to improve ecology dimension's sustainability index. In the management dimension, the main focus of poultry slaughterhouse was improving collaboration with government bodies of other region and improving the suitability of slaughterhouse location with the general 
layout plan of Jakarta. In the technology dimension, improving slaughter system characteristic which was still manual slaughtering into semi-automatic and improving the implementation of good hygiene practices must be the main focus of improvement.

Prospective test on poultry slaughterhouse obtained eight attributes from all dimensions (economy, ecology, social, technology, and management dimensions) with the highest global weight value. According to the prospective test, promotion attributes had the most influence with the least dependence against other attributes, after wastewater utilization (organic fertilizer/biogas) and disease frequency in a year. This might be possible for poultry slaughterhouse was still not widely known by the locals and consumers, which prompts regional government to try improving poultry slaughterhouse promotion in Jakarta City. Efforts to treat wastewater from poultry slaughterhouses can be done by adding activated carbon for the digestion of residual. Blood highly improved the digestion process. The adsorption capacity of ammonium, the protection this carrier may offer by limiting the mass transfer of toxic compounds, and its capacity to act as a conductive material may explain the successful digestion of residual blood as the sole substrate [26]. The last result of PPA in poultry slaughterhouse was disease frequency in a year which slaughterhouse waste is a potential reservoir of pathogenic, viral, prion, and parasitic bacteria that can infect humans and animals. Based on the type of liquid waste management in slaughterhouses that contain blood, protein, fat, and other solid wastes that produce organic substances can be managed through a pasteurization process using the biochemical methane potential process [27]. The liquid waste of slaughterhouses used as fertilizer for plants without going through the processing process can be a source of contamination because liquid slaughterhouses contain pathogenic microorganisms that can cause salmonellosis, leptospirosis, and tularemia [28].

\section{Pig slaughterhouse}

The sustainability of the three dimensions was influenced by main leverage factor, a factor most sensitive to changes. To improve the sustainability of dimensions, treatment must be applied on leverage factor [22]. Leverage factors of the attributes analyzed using leverage factor analysis are obtained from the root mean square (RMS) value which is greater than the median RMS attribute that exists [29]. In pig slaughterhouse, only economy dimension was categorized as moderately sustainable with sustainability index $>50$, whereas other dimensions were categorized as less sustainable. In social dimension, the main leverage factor that must be improved was the acceptance of locals. Based on previous research, $96 \%$ of locals living near the slaughterhouse were disturbed by it [21]. The effort of improving slaughterhouse reception can be by better waste management to prevent disturbing the locals. The most concerning attribute in ecology dimension was the availability of waste monitoring device, such as waste water measuring device, and waste utilization effort into organic fertilizer or biogas, and currently, such efforts were yet to be found in the location. Prospective test on swine slaughterhouse found that slaughterhouse product quality control, liquid waste utilization, production improvement, and employee knowledge level on hygiene and sanitation were attributes most concerning for they have the highest global weight value. All attributes mentioned had high influence with lower dependence compared to other attributes.

\section{Conclusion}

Pig slaughterhouse had the highest value of sustainability among the slaughterhouses with 51.73 index values, while ruminant slaughterhouse had 51.71 values and chicken slaughterhouse was lowest with 45.30. The policy scenario in ruminant slaughterhouses and pig slaughterhouses is to improve the management of slaughterhouse waste into organic fertilizer and energy sources (biogas) and increase the knowledge of abattoir managers by conducting various relevant training; chicken slaughterhouse may improve promotion through print and electronic medium or by social approaches; and pig slaughterhouse also needed to have product quality control through the addition of veterinarians.

\section{Authors' Contributions}

HAS supervised the present study, MM designed and coordinated the study. HAS, MM, NR, and NKP performed the experiment. HAS analyzed the data and wrote the manuscript. The final manuscript has been read and developed in consultation with all authors. All authors read and approved the final manuscript.

\section{Acknowledgments}

The authors thank to Head of the Food, Marine and Agriculture Security Agency of Special Regional Province of the Capital of Jakarta concerning permit to Study in the IPB University with number $8525 /$ 082.74 dated October 26, 2015; to Bogor Agricultural Institute, Indonesia for the support and thank to all respondent.

\section{Competing Interests}

The authors declare that they have no competing interests.

\section{Publisher's Note}

Veterinary World remains neutral with regard to jurisdictional claims in published institutional affiliation.

\section{References}

1. The Center of Statistical Data of Indonesia. (2017) Population of Jakarta Province. Available from: http://www. jakarta.bps.go.id. [Last accessed on 2017 Jun 06]. 
2. Ministry of Agriculture Republic of Indonesia. (2009) Slaughterhouse Operation, Department of Animal Husbandry and Animal Health. Government of Indonesia, Jakarta, Indonesia.

3. Steinhauserova, I. and Borilova, G. (2015) New trends towards more effective food safety control. Proc. Food Sci., 5(2015): 274-277.

4. Cook, E.A.J., de Glanville, W.A., Thomas, L.F., Kariuki, S., Bronsvoort, B.M. and Fèvre, E.M. (2017) Working conditions and public health risks in slaughterhouse in Western Kenya. BMC Public Health, 17(2017): 14.

5. Organization for Economics Cooperation and Development. (2001) The DAC Guideline on Strategies for Sustainable Development. Organization for Economic Cooperation and Development, Paris.

6. Ministry of Health Republic of Indonesia Decree Number 876. (2001) On Technical Guide on Environmental Health Impact Technical Guide on Environmental Health Impact. Ministry of Health Republic of Indonesia, Indonesia.

7. Indonesian National Standard. (1999) Standard of Slaughterhouse in Indonesia. Indonesian National Standard, Indonesia.

8. Waste Water Quality Standard for Slaughterhouse. (2014) Ministry of Forestry and Environment. Ministry of Environment, Forest and Climate Change, New Delhi.

9. Djekic, I. (2015) Environmental impact of meat industry-current status and future perspectives. Procedia Food Sci., 5(2015):61-64.

10. Bustillo-lecompte, C., Mehrvar, M. and Quinonesbolanos, E. (2016) Slaughterhouse wastewater characterization: An economic and public health in Ontario. J. Geosci. Environ. Prot., 4(2016): 175-186.

11. Regional Retribution in Jakarta. (2016) Regional Rule of Jakarta Number 225. Regional Retribution in Jakarta, Jakarta.

12. Nameni, R.P., Kamden, S.S., Ngwa, V.N. and Ngang, J.J.E. (2014) Typology of the Cameroon traditional slaughterhouse based on hygiene practices. Adv. Anim. Vet. Sci., 2(8): 477-487.

13. Regional Rule of Jakarta. (1989) Supervision of Livestock Slaughter and Meat Market. Regional Rule of Jakarta, Jakarta.

14. Kaseinasab, A., Jahangiri, M., Karimi, A., Tabatabaei, R. and Safari, S. (2016) Respiratory disorders among workers in slaughterhouse. Saf. Health Work, 8(1): 84-88.

15. Khalid, R., Knowles, T.G. and Wotton, S.B. (2015) Slaughter of lambs following traditional religious slaughter without stunning, EHOS and PCEHOS. Meat Sci., 110(2015): 15-23.

16. Marques, R.V., da Paz, M.F., Duval, E.H., Correa, L.B. and
Correa, E.K. (2016) Staphylococcus xylosus fermentation of pork fatty waste: Raw material for biodiesel production. Braz. J. Microbiol., 47(3): 675-679.

17. Regional Government of Jakarta Rule Number 1. (2012) On DKI Jakarta Region Spatial Layout Plan. Regional Government of Jakarta, Jakarta.

18. Regional Government of Jakarta Governor Number 28. (2015) On Simplifying Permission and Non-Permission Requirements. Regional Government of Jakarta, Jakarta.

19. Firmansyah, I., Widiatmaka, W., Pramudya, B. and Budiharsono, S. (2016) Sustainability status of rice fields in the production center of Citarum watershed, Romania. J. AAB Bioflux, 8(1): 13-25.

20. Wardani, M.P., Fahrudin, A. and Yulianda, F. (2017) Analysis of Successful Strategy to Develop Sustainable Marine Ecotourism in Gili Bawean Island, Gresik, East Java. IOP Conference Series: Earth and Environmental Science. Vol. 89. East Java.

21. Klintenberg, P., Jamieson, M., Kinyaga, V. and Odlare, M. (2014) Assessing biogas potential of slaughter waste: Can biogas production solve a serious waste problem at abattoirs? Energy Procedia, 61 (2014): 2600-2603.

22. Widiatmaka, W., Munibah, K. and Sitorus, S.R.P. (2017) Appraisal of multidimensional Sustainability land in Karawang Jawa Barat. Kawistara, 5(2): 99-220.

23. Yanuar, Y., Anna, Z., Hindayani, P., Sudradjat, M.F.R. and Zulfiadi, Z.Z. (2018) Prospective analysis of sustainable development strategy of Geopark tourism of CiletuhPalabuhanratu West Java Indonesia. Int. J. Curr. Innov. Res., 42(A): 1033-1039.

24. Sidabalok, H.A., Machfud, M., Nahrowi R. and Pandjaitan, N.K. (2018) Knowledge, attitude and practices slaughterhouse management in special capital region of Jakarta. Sodality J. Rural Sociol., 6(3): 263-271.

25. Ramadhan, D.R., Mulatsih, S. and Amin, A.A. (2015) Sustainable dairy cattle farming systems: A case study of smallholders in Bogor Regency. J. Agro Ekon., 33(1): 51-72.

26. Cuetos, M.J., Martinez, E.J., Moreno, R., Gonzalez, R., Otero, M. and Gomez, X. (2017) Enhancing anaerobic digestion of poultry blood using activated carbon. $J$. $A d v$. Res., 8(3): 297-307.

27. Pilgonde, A.I. (2017) Study on slaughterhouse wastewater treatment by SBR. Int. J. Eng. Res., 6(2): 70-72.

28. Richard, O.B., Okolocha, E.C., Odinya, A.V., Paul, M.P., Audu, D.F. and Adamu, D.A. (2015) Public health risk of abattoir operation in Zango abattoir Zaria, Kaduna state Nigeria. Ann. Res. Rev. Biol., 5(2): 139-146.

29. Walla, N.N., Kusmana, C. and Ramdan, H. (2016) Sustainability study of ecovillage development in the upper basin of Citarum river. J. Nat. Resour. Environ. Manag., 6(2): 131-141.

\section{$* * * * * * * *$}

